\title{
Knowledge, Attitude and Practices of Poultry Farmers on Antimicrobial Use, Resistance and Farm Hygiene Management in Bangladesh
}

\section{Nure Alam Siddiky}

Antimicrobial Resistance Action Center, Bangladesh Livestock Research Institute, Savar, Dhaka-1341, Bangladesh https://orcid.org/0000-0002-1705-7885

\section{Shariful Islam}

EcoHealth Alliance, Institute of Epidemiology, Disease Control and Research (IEDCR), Mohakhali, Dhaka-1212

\section{Md Samun Sarker}

Antimicrobial Resistance Action Center, Bangladesh Livestock Research Institute, Savar, Dhaka-1341, Bangladesh https://orcid.org/0000-0001-5445-1040

\section{Ruhena Begum}

Antimicrobial Resistance Action Center, Bangladesh Livestock Research Institute, Savar, Dhaka-1341, Bangladesh

Mohammed A. Samad ( $\square$ msamad@blri.gov.bd)

Antimicrobial Resistance Action Center, Bangladesh Livestock Research Institute, Savar, Dhaka-1341, Bangladesh https://orcid.org/0000-0001-7329-7325

\section{Research Article}

Keywords: Antimicrobials, AMR, knowledge, attitude, practice, poultry

Posted Date: January 13th, 2022

DOI: https://doi.org/10.21203/rs.3.rs-1256709/v1

License: (c) (i) This work is licensed under a Creative Commons Attribution 4.0 International License. Read Full License 


\section{Abstract}

The poultry farming is considered one of the hotspots for the use of antimicrobials. The knowledge, attitude and practices of poultry farmers are closely associated with the prudent use of antimicrobials in poultry farm practices. A cross sectional study was conducted among seventy-four commercial poultry farms using a pretested structured questionnaire survey to assess knowledge, attitude and practices of the poultry farmers regarding antimicrobial use, resistance and farm hygiene management. According to demographics, more farmers were secondary holders (29.72\%), followed by higher secondary (22.97\%) and illiterate (12.16\%) with least number $(13.51 \%)$ had training on antibiotics but no one had training on AMR. Farmers had sufficient knowledge about antibiotics (86.49\%) but inadequate knowledge about antimicrobials (14.86\%), AMR (51.35\%), and animal and fish feed act (20.27\%). The majority of farmers strongly agreed that AMR had a negative impact on production (40.54\%), human health (36.49\%), environment (33.78\%) and economy (52.7\%). Farm hygiene management revealed that most of them (90.54\%) thrown the expired and leftover antibiotics in the open environments. Furthermore, the farm litter was managed diversely with $39.19 \%$ kept in open pit; $33.78 \%$ used in fish farm and $5.41 \%$ used for agricultural land. It was observed that the dead birds were disposed in a variety of ways, buried into ground (58.10\%), thrown into field (9.45\%), thrown into bush (6.75\%), thrown into garbage $(9.45 \%)$ and thrown in the water (13.51\%). A significant higher association was found between the level of education and knowledge; level of education with farm practices such as choice of antibiotics, determining doses and duration of antibiotics, disposal of farm wastages, disposal of dead birds, farm biosecurity and vaccination coverage $(p<0.05)$. Continuous education, hands-on training, awareness, and motivation of farmers along with good biosecurity, mass vaccination and proper hygienic measures can minimize the uses of antimicrobials in farm operations.

\section{Introduction}

The poultry subsector plays an important role in promoting agricultural growth and reducing malnutrition in Bangladeshi people (Da Silva and Rankin, 2014; Hamid et al., 2017). Bangladesh's commercial poultry production is growing rapidly to meet the increasing demand for poultry meat and eggs (Imam et al., 2020). It is an integral part of Bangladesh's agricultural system, creating direct and indirect employment opportunities including support services for about 6 million people (Ansari-Lari et al., 2010). Poultry accounts for about 22-27\% of the country's total animal protein supply (Hamid et al., 2017). The total investment in the poultry sector is about BDT 35,000 crore and it has created employment opportunities for over 6 million people, majority of them are unemployed youth and women (Saleque and Silvi, 2020). The country has approximately 100 breeder farms \& hatcheries, 8 grandparent stock farms, 70,000 commercial layer \& broiler farms, more than 200 feed mills and 500 animal health companies (http://wpsa-bb.com/poultry-at-a-glance/). Small scale commercial poultry farm defined as having less than 5,000 birds in each batch (Begum et al., 2013). It accounts for $81 \%$ of the commercial poultry sector, which contributes for about $78 \%$ of the total poultry meat supply in Bangladesh (BBS, 2017). Smallholder poultry farms are usually traditional open system houses with natural ventilation, manual feeding and open walls.

In Bangladesh, the level of antibiotic use in animal production is unknown (Khatun et al., 2016) and data on the sale of antibiotics nationwide are unreliable (Ferdous et al., 2019). In addition, frequent sales of antimicrobials by feed and chick traders, and representatives of pharmaceutical companies indicate a lack of governance in the use of antimicrobial agents in Bangladesh (Masud et al., 2020). In addition, there are no regulations on the registration and labeling of veterinary drugs (DGDA, 2016), nor are there specific guidelines for the use of antimicrobials in livestock (Ferdous et al., 2019). Furthermore, it has been shown that farmers often do not follow the dose and duration recommended by the manufacturer when administering antibiotics to livestock and poultry (Khatun et al., 2016). Antimicrobials are commonly used to treat and prevent poultry diseases, but some farmers use them to promote growth to increase feed conversion ratios (Saiful Islam et al., 2016). 
There is increasing concern about the use of antimicrobials in animal feed production and the risk of transmission of antibiotic resistance in the food chain (Laxminarayan et al., 2013). In commercial poultry farms, antimicrobials are more likely to be used for therapeutic purposes without veterinary supervision. Antimicrobials are also used in sub-therapeutic doses by adding them to food and water for prevention, growth promotion, and risk management strategies (Begum et al., 2013). Sub-therapeutic uses of antimicrobials are prevalent in both human medicine and livestock production (Broom et al., 2014). In Bangladesh, the animal and fish feed act, 2010 prohibits the use of antimicrobials in feed (MoFL, 2010). However, poultry farmers may violate the law by adding antibiotics either in feed and drinking water and provided to chicken. Moreover, governance along with monitoring and surveillance on the poultry farmers are very weak and irregular.

Nonetheless, AMR has been spreading rapidly since last decade and has become a global threat, ultimately causes treatment failure both in humans and animals (Hassan et al., 2020). Lack of legal enforcement of regulation, and selfprescription by farmers, are responsible for the development of AMR, which poses a significant threat to public health around the world (WHO, 2021). In Bangladesh most of the poultry farming community are illiterate and they have poor knowledge on rational use of antimicrobials in the production cycle. Most of the poultry farmers are persuaded or motivated by the feed seller or chick seller or pharmaceutical companies to the use of antimicrobials (Masud et al., 2020). The government of Bangladesh has adopted National Action Plan (NAP) on AMR for the year 2017-2021 but unfortunately the antimicrobial stewardship program in animal health sector was not addressed (MoHFW, 2017).

The rapid growth of poultry farms over time, the accumulation of waste, especially litter and manure, has increased, resulting in environmental impact (Adeoye et al., 2014; Onu et al., 2015). Proper farm hygiene management is a remedy for a long-term productivity, growth and environmental sustainability of the poultry farm. The poultry farm generates abundant amount of solid waste like bedding material (wood shavings, saw dust, straw, rice hulls), feed, feathers, hatchery waste, and waste water with feces, urine, drug and pesticide residues (Moreki and Keaikitse, 2013; Onu et al., 2015). Poultry farm waste contains some essential nutrients which helps in crop cultivation, soil health management and agricultural production (Chan et al., 2008). It also contains microorganisms, hormone, antibiotic and heavy metal residues (Abah et al., 2019). Poultry waste contains high moisture with organic materials, which create environmental problem such as fly breeding, odour nuisance and greenhouse gas emission if not disposed of or managed properly (Singh et al., 2018). The dead bird waste is another important driver for the spread of infectious disease as well as environmental pollution (Adeoye et al., 2014).

Poultry farms are considered a hotspot for the use of antimicrobials to treat and prevent diseases. It is also considered the warehouse for spreading of infectious diseases and environmental pollution. It is a demand of time to prevent or reduce the unnecessary and unethical use of antimicrobials in poultry production systems though good farming practices. We can reduce the misuse and overuse of antimicrobials by means of farmer education, motivation, training and awareness building campaigns. There is a scarcity of quality and reliable information about the farmer's knowledge, perception and practices regarding uses of antimicrobials, leading to the development of antimicrobial resistance and farm hygiene management. Considering the backdrop, this study has been undertaken to find out the knowledge, attitude and practices of the poultry farmers regarding the use of antimicrobials, emergence of antimicrobial resistance and farm hygiene management in Bhaluka, Mymensingh, Bangladesh. The study would reveal knowledge and practice gaps of the farmers and suggests some possible interventions to be needed to minimize the threat of AMR in poultry production system.

\section{Materials And Methods}

\subsection{Study design and location}


A cross-sectional study was conducted from July 2020 to January 2021 among the seventy-four poultry farmers (Seventy-three layer and one broiler) at six villages namely Panihadi, Ditpur, Randia, Dholia, Badepurura and Bohuli at Ditpur Union in Bhaluka sub-district of Mymensingh district. The selected villages were characterized by higher concentration of layer farms with integrated aquaculture farming. The layer farms were mostly medium-scale with flock size 2000 to 3000 birds. Most of the poultry farm wastages were used for aquaculture farming. The layer farms were traditionally managed with minimum or no Good Veterinary Practices (GVP), Good Animal Husbandry Practices (GAHP), Good Agricultural Practices (GAP) along with poor biosecurity measures.

\subsection{Questionnaire}

The structured questionnaire was adopted from a previously published study with significant modifications to meet the objectives of this study (Pham-Duc et al., 2019). We conducted the survey using KoBoCollect software on smartphones. Kobo collect is a user-friendly tool for collecting, compiling, and interpreting field data. The questionnaire was reviewed by a panel of experts consisting of public health professionals, microbiologists and epidemiologists with extensive experience in food safety and antibiotic resistance. In addition, the questionnaire has been translated into Bengali to facilitate communication with farmers. The questionnaire was divided into four different parts, including general and demographic information, knowledge, attitudes and practices. The farmers were interviewed to elicit their knowledge, attitudes and self-reported practices with regards to antimicrobial use (AMU) and resistance.

Major points were captured by the questionnaire included (i) general information of the respondents/ farmers (e.g. gender, age, education, and main occupation) and their households, poultry farming activities (e.g. number of birds, breed type, feeds \& feedings, sources of water, shed type, rearing method, sources of feed, day old chick, purchase of farm inputs, formal/ informal negotiations/ agreement with feed/ chick suppliers and farm waste management), (iii) knowledge about antimicrobial use (AMU) and antimicrobial resistance (AMR) (e.g. understanding with antimicrobials, antimicrobials resistance, name of common antimicrobials, causes of using antibiotics, causes of emergence of AMR, participation in training on AMU, AMR; proper doses and duration of antibiotics; antibiotic withdrawal period; relation between antibiotic use and its resistance etc.), (iv) attitudes towards AMU and AMR (e.g. awareness of AMR effects, potential AMU, and attitude towards using antibiotics for disease prevention or growth promotion, importance of biosecurity, training, vaccination for good farm management), (v) practices on AMU and farm operations (e.g. technical support and suggestions for farm management, measures undertaken when poultry became sick, when and how administer antibiotics to chicken, frequency and doses of antibiotics, disposal of leftover antibiotics, farm waste/ litter management system, uses of disinfectant and footbath for farm biosecurity). The interviewee was the farm management decisionmakers who had detailed information related to questionnaire.

\section{Figure 1}

Map indicating the survey areas in Bhaluka sub-districts

\subsection{Data Management and analysis}

The data was extracted into an MS Excel spreadsheet for cleaning, processing, and further analysis. Each validated question was analyzed individually and the answers were assigned a score of 1 (correct) or 0 (incorrect). The sum of the responses of each participant in that section was calculated to analyze how each farmer behaved overall in each category of knowledge, attitude and practice. Those who are considered to have more than $50 \%$ correct answers to any section of the questionnaire (or reflect practices that impede the development of AMR) may have been evaluated as positive knowledge, attitudes, or practices.

\subsection{Statistical analysis}


The data was analyzed using software version 20 of the Social Science Statistics Package (SPSS). We summarized the data using categories and descriptive statistics such as mean frequency (\%) and numerical standard deviation (SD). The chi-square test $(\chi 2)$ was used to clarify the relationship between sociodemographic characteristics and the value of knowledge, attitude, and practice. Statistical significance was measured with a p-value less than $0.05(p<0.05)$.

\section{Results}

\subsection{Demographic and general information}

The interview has been conducted in seventy-four farms consisting of 33 (44.59\%) in PaniHadi, 13 (17.56\%) in Randia, 5 (6.7\%) in Ditpur, 19 (25.67\%) in Dholia, 2 (2.7\%) in Badepurara and 2 (2.7\%) in Bohuli villages respectively. Almost all of the farmers were male (98.65\%) with a single was female (1.35\%). Majority farmers $(43.24 \%)$ had been aged below 30 years old whilst, second highest number of farmers (39.18\%) had been aged between 30 to 45 years old and only a single had upper 60 years old. The foremost of the interviewee (86.48\%) himself was farm owner followed by manager (9.45\%) and remaining was part time workers (4.05\%). Maximum farmers had secondary education (29.72\%) followed by bachelor degree (22.97\%), higher secondary (18.91\%), primary education (16.21\%) and some had no formal education (12.16\%). Poultry farming used to be the secondary occupation of the most of the farmers (51.35\%) whereas, almost half (48.64\%) of the farmers it had principal occupation. Of all farmers, $49 \%$ had $4-6$ years, $31 \%$ had less than 3 years and $9 \%$ had more than 10 years farming experiences. Most of the farm (66.21\%) had single shed and $31.08 \%$ farms had been running between 3 to 5 batches of poultry. A total of $91.9 \%$ farm owners had no formal contract with the feed/chick traders, and $41.89 \%$ purchased feed and chicks by cash. It was found that $32.44 \%$ farms faced antibiotic treatment failure in the last six months (Table 1). 
Table 1

General features of the poultry farms in the study area

\begin{tabular}{|c|c|c|c|}
\hline Item & $n$ & $\%$ & Mean $\pm S D$ \\
\hline \multicolumn{4}{|c|}{ Location of the sampling area (Villages) } \\
\hline Pani Hadi & 33 & 44.59 & \multirow[t]{6}{*}{$16.42 \pm 12.33$} \\
\hline Randia & 13 & 17.56 & \\
\hline Ditpur & 05 & 6.7 & \\
\hline Dholia & 19 & 25.67 & \\
\hline Badepurura & 02 & 2.7 & \\
\hline Bohuli & 01 & 1.35 & \\
\hline \multicolumn{4}{|l|}{ Gender } \\
\hline Male & 73 & 98.65 & \\
\hline Female & 01 & 1.35 & \\
\hline \multicolumn{4}{|l|}{ Age (years old) } \\
\hline$<30$ & 32 & 43.24 & \multirow[t]{4}{*}{$24.99 \pm 14.62$} \\
\hline $30-45$ & 29 & 39.18 & \\
\hline $46-60$ & 12 & 16.21 & \\
\hline$>60$ & 01 & 1.35 & \\
\hline \multicolumn{4}{|c|}{ Role of the interviewee in the farm management } \\
\hline Owner & 64 & 86.48 & \multirow[t]{3}{*}{$33.32 \pm 34.12$} \\
\hline Manager & 07 & 9.45 & \\
\hline Worker & 03 & 4.05 & \\
\hline \multicolumn{4}{|l|}{ Education } \\
\hline None & 09 & 12.16 & \\
\hline Primary & 12 & 16.21 & \\
\hline Secondary school & 22 & 29.72 & \\
\hline Higher secondary & 14 & 22.97 & \\
\hline Bachelor/Masters & 17 & 18.91 & \\
\hline \multicolumn{4}{|c|}{ Main occupation of the farm owner } \\
\hline Poultry farming & 36 & 48.64 & \\
\hline Others & 38 & 51.35 & \\
\hline \multicolumn{4}{|c|}{ How long have you been involved with poultry farming? } \\
\hline$\leq 3$ & 23 & 31.08 & $24.99 \pm 1.41$ \\
\hline $4-6$ & 36 & 48.64 & \\
\hline
\end{tabular}




\begin{tabular}{|c|c|c|c|}
\hline Item & $\mathbf{n}$ & $\%$ & Mean $\pm S D$ \\
\hline $7-10$ & 06 & 8.10 & \\
\hline$\geq 11$ & 09 & 12.16 & \\
\hline \multicolumn{4}{|l|}{ Who is decision maker of your farms? } \\
\hline Manager & 06 & 8.10 & \\
\hline Owner & 68 & 91.90 & \\
\hline \multicolumn{4}{|l|}{ Number of sheds in the farm } \\
\hline 1 & 49 & 66.21 & \\
\hline$>1$ & 25 & 33.79 & \\
\hline \multicolumn{4}{|c|}{ Number of poultry batches previously reared in this farm } \\
\hline Zero & 28 & 37.83 & \\
\hline $1-2$ & 19 & 25.67 & \\
\hline $3-5$ & 23 & 31.08 & \\
\hline$>5$ & 04 & 5.40 & \\
\hline \multicolumn{4}{|l|}{ What type of poultry reared? } \\
\hline Layer & 73 & 98.65 & \\
\hline Broiler & 01 & 1.35 & \\
\hline \multicolumn{4}{|c|}{ Does farm workers live within the farm permanently? } \\
\hline Yes & 14 & 18.92 & \\
\hline No & 60 & 81.08 & \\
\hline \multicolumn{4}{|c|}{ Does farm worker work in multiple shed simultaneously? } \\
\hline Yes & 06 & 8.1 & \\
\hline No & 68 & 91.9 & \\
\hline \multicolumn{4}{|c|}{ Does any written contract with individual or company for supply of feed and chicken? } \\
\hline No & 68 & 91.9 & \\
\hline Yes & 06 & 8.1 & \\
\hline \multicolumn{4}{|c|}{ What is mode of payment for buying of chicken, feed and medicine? } \\
\hline All in cash & 31 & 41.89 & \\
\hline All in credit & 03 & 4.05 & \\
\hline Sometimes in cash and sometimes in credit & 40 & 54.05 & \\
\hline \multicolumn{4}{|l|}{ What are the sources of drinking water? } \\
\hline Piped water & 37 & 50 & \\
\hline Tube well & 37 & 50 & \\
\hline
\end{tabular}




\begin{tabular}{|c|c|c|c|}
\hline Item & $\mathbf{n}$ & $\%$ & Mean $\pm S D$ \\
\hline \multicolumn{4}{|c|}{ Do you treat the drinking water? } \\
\hline Yes & 04 & 5.40 & \\
\hline No & 70 & 94.60 & \\
\hline \multicolumn{4}{|c|}{ Have you noticed any clinical signs in this flock? } \\
\hline Yes & 62 & 83.78 & \\
\hline No & 12 & 16.22 & \\
\hline \multicolumn{4}{|c|}{ Did you face treatment failure (no response to treatment with antibiotic) within last 6 months? } \\
\hline Yes & 24 & 32.44 & \\
\hline No & 50 & 67.56 & \\
\hline
\end{tabular}

\subsection{Knowledge of the poultry farmers}

Of the 74 chicken producers, $85.14 \%$ had no knowledge of antimicrobials, while $86.49 \%$ had knowledge of antibiotics. Nearly $100 \%$ had no idea about the differences between antimicrobials and antibiotics. A number of $83.78 \%$ respondent said they were using antibiotics for therapeutic purposes while $89.19 \%$ agreed antibiotics to be used according to prescriber guidelines. Approximately $37.84 \%$ believed that antibiotics may be used for the treatment of both bacterial and viral diseases. Almost $51.35 \%$ of respondents have heard about antimicrobial resistance and $58.11 \%$ believed AMR is the cause of treatment failure. Approximately $90.54 \%$ were not aware about the "animal and fish feed act, 2010" and approximately $44.59 \%$ believed that all commercially available feeds contained antibiotics. At best, $13.51 \%$ farmers attended the training on the use of antibiotics in the poultry production cycle, but no one received training on antimicrobial resistance. Nearly $60.81 \%$ believed that all antibiotics can be used for both humans and animals. About $71.62 \%$ believed that higher doses of antibiotics could provide better results in treatments. Nearly $86.49 \%$ felt that improper use of antibiotics had an economic impact on farm management. Almost $71.62 \%$ had conception that antibiotics can be used as growth promoters and $54.05 \%$ said antibiotics can be used for disease prevention. About $66.22 \%$ of respondents believed that the withdrawal period should be maintained before selling/slaughtering of chicken. Nearly $62.16 \%$ thought that there was no relationship between antibiotic use and antibiotic resistance. The detail of farmer knowledge has given in Table 2A, 2B and 2C. 
A. Knowledge of the poultry farmers

\begin{tabular}{|c|c|c|}
\hline \multirow[t]{2}{*}{ Knowledge } & \multicolumn{2}{|l|}{$\mathrm{n}(\%)$} \\
\hline & Yes & No \\
\hline 1. 1. Are you familiar with antimicrobials? & $11(14.86)$ & $63(85.14)$ \\
\hline 2. 2. Are you familiar with the concept of antibiotic? & $64(86.49)$ & $10(13.51)$ \\
\hline 3. 3. Have you ever heard about antibiotic resistance? & $38(51.35)$ & $36(48.65)$ \\
\hline $\begin{array}{l}\text { 4. 4. Do you know there is an act named "Animal and Fish Feed Act- } \\
\text { 5. 2010"? }\end{array}$ & $15(20.27)$ & $59(79.73)$ \\
\hline $\begin{array}{l}\text { 6. 5. Have you ever attended any training on using antibiotics in } \\
\text { 7. poultry production? }\end{array}$ & $10(13.51)$ & 64(86.49) \\
\hline 8. 6. Have you ever attended any training on antibiotic resistance? & $0(0)$ & $74(100)$ \\
\hline
\end{tabular}

Table 2

B. Knowledge of the poultry farmers

\begin{tabular}{|c|c|c|c|}
\hline \multirow[t]{2}{*}{ Knowledge } & \multicolumn{3}{|l|}{$\mathrm{n}(\%)$} \\
\hline & Correct & Wrong & No idea \\
\hline $\begin{array}{l}\text { 1. "Antibiotics need to be used according to prescription/practitioners guides" } \\
\text { is it correct or wrong? }\end{array}$ & $66(89.19)$ & $3(4.05)$ & $5(6.76)$ \\
\hline $\begin{array}{l}\text { 2. "Antibiotics can provide better result at higher dose for diseases treatment" } \\
\text { is it correct or wrong? }\end{array}$ & $53(71.62)$ & $8(10.81)$ & $13(17.57)$ \\
\hline $\begin{array}{l}\text { 3. "Many antibiotics have no effectiveness in animal treatment, even at high } \\
\text { dose" is it correct or wrong? }\end{array}$ & $38(51.35)$ & 14(18.92) & $22(29.73)$ \\
\hline 4. "Improper use of antibiotics are costly for farmers" is it correct or wrong? & $64(86.49)$ & $2(2.70)$ & $8(10.81)$ \\
\hline $\begin{array}{l}\text { 5. "Need to use antibiotic to promote growth in poultry/livestock" is it } \\
\text { correct/wrong? }\end{array}$ & $53(71.62)$ & $7(9.46)$ & 14(18.92) \\
\hline $\begin{array}{l}\text { 6. "Need to use antibiotic for prevention of diseases in poultry/livestock" is it } \\
\text { correct/wrong? }\end{array}$ & $40(54.05)$ & 20(27.03) & 14(18.92) \\
\hline $\begin{array}{l}\text { 7. "Need to use antibiotic for treatment of diseases in poultry/livestock" is it } \\
\text { correct/wrong? }\end{array}$ & $62(83.78)$ & $1(1.35)$ & 11(14.86) \\
\hline $\begin{array}{l}\text { 8. "Overuse of antibiotics can lead to slow growth of chicken due to effects to } \\
\text { digestion" is it wrong or correct? }\end{array}$ & $46(62.16)$ & $6(8.11)$ & $22(29.73)$ \\
\hline 9. "Often using antibiotics help quick growth of chicken" is it correct/wrong? & $27(36.49)$ & $17(22.97)$ & $30(40.54)$ \\
\hline $\begin{array}{l}\text { 10. "Should have a sufficient/appropriate withdrawal time before selling } \\
\text { chicken for slaughtering" is it correct or wrong? }\end{array}$ & $49(66.22)$ & $0(0)$ & $25(33.78)$ \\
\hline $\begin{array}{l}\text { 11. "Antibiotic can kill the beneficial bacteria of poultry, as well" is it } \\
\text { correct/wrong? }\end{array}$ & $31(41.89)$ & $1(1.35)$ & $42(56.76)$ \\
\hline $\begin{array}{l}\text { 12. Do you think, frequent uses of antibiotics in animals will affect to } \\
\text { effectiveness of antibiotics in human health? }\end{array}$ & $38(51.35)$ & $9(12.16)$ & $27(36.49)$ \\
\hline $\begin{array}{l}\text { 13. Do you think, there is a relationship between antibiotic use and antibiotic } \\
\text { resistance? }\end{array}$ & $24(32.43)$ & $4(5.41)$ & $46(62.16)$ \\
\hline
\end{tabular}




\section{Knowledge}

Number (n) Percentage (\%)

1. 1. Do you think all antibiotics can be used in both human and animals?

Yes

60.81

No

6

8.11

Don't know

23

31.08

2. 2. Do you know any kind of antibiotics that are not allowed to use in poultry production?

Yes

14

18.92

No

13

17.57

Don't know

47

63.51

3. 3. Do you think that antibiotic is different from antimicrobials?

Know

0

0

Don't know

74

100

4. 4. When do you mostly use antibiotics?

Disease treatment

62

83.78

Prevention of infection

2

2.70

Promoting growth

2

2.70

Whenever I want to use

2

2.70

Don't know

6

8.11

5. Which diseases are antibiotics used for?

Bacterial

11

9

Viral

Both

Don't know

6. 6. What is antibiotic resistance?

It causes poor response to treatment

It causes treatment failure

It is dangerous but I do not know how to describe it

Others

7. What do you think about the use of antibiotics in animal feed?

All ready feed contain antibiotics

Some ready feed contain antibiotics

None of the feed contain any antibiotics
4

43

2

25

33

44.59

2

2.70

13
14.86

12.16

37.84

35.14

5.41

58.11

2.70

33.78

Page 10/25 


\begin{tabular}{|lcc|}
\hline Knowledge & Number (n) & Percentage (\%) \\
\hline I don't know & 26 & 35.14 \\
\hline 8. 8. What do you know about "Animal and Fish Feed Act-2010" & 5 & 6.76 \\
\hline Antibiotic use in feed is prohibited & 67 & 90.54 \\
\hline I have no idea & 1 & 1.35 \\
\hline No antibiotic allowed to use in feed and if used, should follow the withdrawal period & 1 & 1.35 \\
\hline No antibiotic used in feed & & \\
\hline
\end{tabular}

\subsection{Attitude of the poultry farmers}

Of all the poultry farmers, $62.16 \%$ respondents told it would be more serious if antibiotics didn't work against an infection in humans whilst $48.65 \%$ thought it would be very serious if antibiotics can't work in livestock or poultry infection.

Approximately $66.22 \%$ of respondents strongly agreed that antibiotics can protect humans and animals against infection. Only $37.84 \%$ strongly agreed that appropriate use of antibiotics can decrease the risk of antimicrobial resistance. About $43.24 \%$ strongly disagreed that antibiotics are not needed for disease prevention whilst about $50 \%$ strongly disagreed that antibiotics are not needed for growth promotion. Nearly $56.76 \%$ stated that a veterinarian or animal health practitioner should be consulted prior to the use of antibiotics. Only $44.59 \%$ strongly agreed that the antibiotic withdrawal period should be followed prior selling of poultry for human consumption. Overall, $40.54 \%$ of respondents strongly believed that AMR had a negative impact on poultry production, while $36.49 \%$ strongly agreed that AMR had a negative impact on human health. A considerable number of respondents strongly agreed that antibiotics had negative impact on environment (33.78\%) and the economy (52.70\%). It was said by the respondents that proper biosecurity $(54.05 \%)$ and vaccination $(60.81 \%)$ can reduce the use of antibiotics. A total of $72.97 \%$ farmers were very much interested in learning about antibiotics and $87.84 \%$ said should be consulted with physician before using antibiotics. The detail of farmer attitude has given in Table 3A, 3B and 3C.

Table 3

A. Attitudes of the poultry farmers

\begin{tabular}{|c|c|c|c|c|}
\hline \multirow[t]{2}{*}{ Attitudes } & \multicolumn{4}{|l|}{ n (\%) } \\
\hline & $\begin{array}{l}\text { Very } \\
\text { serious }\end{array}$ & Serious & $\begin{array}{l}\text { Less } \\
\text { serious }\end{array}$ & Neutral \\
\hline $\begin{array}{l}\text { 1. When an infection in human being cannot be treated with antibiotics, } \\
\text { how serious do you think it could be? }\end{array}$ & $\begin{array}{l}46 \\
(62.16)\end{array}$ & $\begin{array}{l}21 \\
(28.38)\end{array}$ & $\begin{array}{l}2 \\
(2.70)\end{array}$ & $\begin{array}{l}5 \\
(5.76)\end{array}$ \\
\hline $\begin{array}{l}\text { 2. When an infection in animal cannot be treated with antibiotics, how } \\
\text { serious do you think it could be? }\end{array}$ & $\begin{array}{l}36 \\
(48.65)\end{array}$ & $\begin{array}{l}28 \\
(37.84)\end{array}$ & $\begin{array}{l}5 \\
(6.76)\end{array}$ & $\begin{array}{l}5 \\
(6.76)\end{array}$ \\
\hline
\end{tabular}


Table 3

B. Attitudes of the poultry farmers

\begin{tabular}{|c|c|c|c|c|c|}
\hline \multirow[t]{2}{*}{ Attitudes } & \multicolumn{5}{|l|}{$\mathrm{n}(\%)$} \\
\hline & $\begin{array}{l}\text { Strongly } \\
\text { agree }\end{array}$ & Agree & Neutral & Disagree & $\begin{array}{l}\text { Strongly } \\
\text { disagree }\end{array}$ \\
\hline $\begin{array}{l}\text { 1. Can antibiotics protect both human and animal } \\
\text { from diseases? }\end{array}$ & $\begin{array}{l}49 \\
(66.22)\end{array}$ & $6(8.11)$ & $2(2.70)$ & $\begin{array}{l}17 \\
(22.97)\end{array}$ & 0 \\
\hline $\begin{array}{l}\text { 2. When using antibiotics properly, there is less risk } \\
\text { of antibiotic resistance }\end{array}$ & $\begin{array}{l}28 \\
(37.84)\end{array}$ & $\begin{array}{l}14 \\
(18.92)\end{array}$ & $\begin{array}{l}22 \\
(29.73)\end{array}$ & $9(12.16)$ & $1(1.35)$ \\
\hline $\begin{array}{l}\text { 3. It is important to use antibiotics in disease } \\
\text { treatment }\end{array}$ & $\begin{array}{l}28 \\
(37.84)\end{array}$ & $\begin{array}{l}14 \\
(18.92)\end{array}$ & $\begin{array}{l}22 \\
(29.73)\end{array}$ & $9(12.16)$ & $1(1.35)$ \\
\hline $\begin{array}{l}\text { 4. It is important to use antibiotics in disease } \\
\text { prevention }\end{array}$ & $2(2.70)$ & $9(12.16)$ & $\begin{array}{l}16 \\
(21.62)\end{array}$ & $\begin{array}{l}15 \\
(20.27)\end{array}$ & $\begin{array}{l}32 \\
(43.24)\end{array}$ \\
\hline $\begin{array}{l}\text { 5. It is important to use antibiotics in promoting } \\
\text { growth in chicken production }\end{array}$ & $5(6.76)$ & $1(1.35)$ & $\begin{array}{l}11 \\
(14.86)\end{array}$ & $\begin{array}{l}20 \\
(27.02)\end{array}$ & $37(50)$ \\
\hline $\begin{array}{l}\text { 6. Using antibiotics needs prescriptions from } \\
\text { veterinarians'/animal health practitioners }\end{array}$ & $\begin{array}{l}42 \\
(56.76)\end{array}$ & 12(16.22) & $\begin{array}{l}10 \\
(13.51)\end{array}$ & $9(12.16)$ & $1(1.35)$ \\
\hline $\begin{array}{l}\text { 7. Withdrawal period should follow before selling } \\
\text { poultry/livestock is necessary }\end{array}$ & $\begin{array}{l}33 \\
(44.59)\end{array}$ & $\begin{array}{l}15 \\
(20.27)\end{array}$ & $\begin{array}{l}16 \\
(21.62)\end{array}$ & $8(10.81)$ & $2(2.70)$ \\
\hline $\begin{array}{l}\text { 8. Antibiotic resistance has negative impacts on } \\
\text { chicken production }\end{array}$ & $\begin{array}{l}30 \\
(40.54)\end{array}$ & $9(12.16)$ & $\begin{array}{l}20 \\
(27.03)\end{array}$ & $\begin{array}{l}13 \\
(17.57)\end{array}$ & $2(2.70)$ \\
\hline $\begin{array}{l}\text { 9. Antibiotic resistance has negative impacts on } \\
\text { human health }\end{array}$ & $\begin{array}{l}27 \\
(36.49)\end{array}$ & $\begin{array}{l}12 \\
(16.22)\end{array}$ & $\begin{array}{l}24 \\
(32.43)\end{array}$ & $\begin{array}{l}10 \\
(13.51)\end{array}$ & $1(1.35)$ \\
\hline $\begin{array}{l}\text { 10. Antibiotic resistance has negative impacts on } \\
\text { environment }\end{array}$ & $25(33.78)$ & 13(17.57) & 25(33.78) & $9(12.16)$ & $2(2.70)$ \\
\hline $\begin{array}{l}\text { 11. Antibiotic resistance has negative impacts on } \\
\text { economy }\end{array}$ & $\begin{array}{l}39 \\
(52.70)\end{array}$ & 14(18.91) & 12(16.22) & $9(12.16)$ & $0(0)$ \\
\hline $\begin{array}{l}\text { 12. Apply hygiene and biosecurity measure is } \\
\text { important in livestock activities }\end{array}$ & $40(54.05)$ & $15(20.27)$ & $10(13.51)$ & $9(12.16)$ & $0(0)$ \\
\hline 13. Vaccination is essential in poultry farming & $45(60.81)$ & 12(16.22) & $9(12.16)$ & $8(10.81)$ & $0(0)$ \\
\hline 14. Keep stock density according to farm capacity & $42(56.77)$ & 13(17.57) & 11(14.86) & $8(10.81)$ & $0(0)$ \\
\hline $\begin{array}{l}\text { 15. Antibiotic should be used as per standard } \\
\text { guidelines }\end{array}$ & $42(56.77)$ & $13(17.57)$ & 12(16.22) & $6(8.11)$ & $1(1.35)$ \\
\hline $\begin{array}{l}\text { 16. Farmers need to provide training, assistance, } \\
\text { guidance by veterinarian/ vet authorities in using } \\
\text { antibiotics }\end{array}$ & $40(54.05)$ & $11(14.86)$ & 14(18.91) & $8(10.81)$ & $1(1.35)$ \\
\hline $\begin{array}{l}\text { 17. Farmers need to provide briefing about doses } \\
\text { and duration of antibiotics during prescribing/ } \\
\text { buying antibiotics }\end{array}$ & $43(58.11)$ & $11(14.86)$ & $11(14.86)$ & $8(10.81)$ & $1(1.35)$ \\
\hline $\begin{array}{l}\text { 18. Drug store/company need to certify and closely } \\
\text { monitor by the authority }\end{array}$ & $42(56.77)$ & $11(14.86)$ & $13(17.57)$ & $8(10.81)$ & $0(0)$ \\
\hline $\begin{array}{l}\text { 19. Ensure a sufficient/appropriate withdrawal time } \\
\text { before selling to avoid residue in livestock/poultry }\end{array}$ & $32(43.24)$ & 12(16.22) & $20(20.03)$ & $10(13.51)$ & $0(0)$ \\
\hline
\end{tabular}




\section{Attitudes}

Number (n)

Percentage (\%)

1. When do you think your chicken need antibiotics the most?

$\begin{array}{llc}\text { Have a disease } & 64 & 86.49 \\ \text { Have any abnormal symptoms/signs } & 8 & 10.81 \\ \text { Guidance/suggestion from other people } & 2 & 2.70\end{array}$

2. What would be the first thing you do, if you think that your chicken get disease?

\begin{tabular}{|lll|}
\hline Ask private veterinarian & 48 & 64.87 \\
\hline Ask Govt. veterinarian & 10 & 13.51 \\
\hline Ask neighbor farmers & 3 & 4.05 \\
\hline Self-medication & 4 & 5.41 \\
\hline Ask drug seller & 5 & 6.75 \\
\hline Ask veterinary para-professional & 1 & 1.35 \\
\hline Isolation of sick bird outside the shed & 1 & 1.35 \\
\hline Isolation of sick bird within the shed & 1 & 1.35 \\
\hline Other (specify) & 1 & 1.35 \\
\hline 3. Please rate your interest in learning more about antibiotics & & 72.97 \\
\hline Very interested & 54 & 13.51 \\
\hline Interested & 10 & 12.16 \\
\hline Neutral & 9 & 1.35 \\
\hline Not interested & 1 & \\
\hline
\end{tabular}

4. Use of antibiotics is necessary to improve the productivity of poultry

\begin{tabular}{|lcc|}
\hline Very important & 3 & 4.05 \\
\hline Important & 5 & 6.76 \\
\hline Neutral & 18 & 24.32 \\
\hline Less important & 11 & 14.86 \\
\hline Not important & 37 & 50
\end{tabular}

5. Do you think you should always consult with veterinarian before any use of antibiotics?

$\begin{array}{lll}\text { Yes } & 65 & 87.84 \\ \text { No } & 9 & 12.16\end{array}$

6. Do you think restriction of antibiotics in poultry will be harmful than that of benefit

$\begin{array}{lll}\text { Yes } & 46 & 62.16 \\ \text { No } & 15 & 20.27\end{array}$




\begin{tabular}{|lcc|}
\hline Attitudes & \multicolumn{1}{l}{ Number (n) } & Percentage (\%) \\
\hline I don't know & 13 & 17.57 \\
\hline 7. If you use antibiotics in your farm, do you want to substitute & it with alternatives & which are not antibiotics? \\
\hline Yes & 53 & 71.62 \\
\hline No & 15 & 20.27 \\
\hline Don't answer & 6 & 8.11 \\
\hline
\end{tabular}

\subsection{Practices of the poultry farmers}

A total of $60.81 \%$ farmers took veterinary services from non-governmental private veterinary professionals whereas only $13.51 \%$ took veterinary services from the government veterinary physician. Approximately $87.84 \%$ of farmers used antibiotics for treatment whereas $5.41 \%$ used as preventive measures. Antimicrobial susceptibility testing was not carried out generally prior prescribing antibiotics. About $87.84 \%$ of farmers used antibiotics in accordance with the manufacturer's instructions. Nearly $94.59 \%$ of farmers bought antibiotics from drug shop/ pharmacy and only $4.05 \%$ bought directly from a pharmaceutical company. Nearly $59.46 \%$ of farmers took prescriptions and $35.14 \%$ received verbal advice before using antibiotics. A reasonable number of farmers $(13.51 \%)$ used previous prescription for the therapeutic uses of antibiotics in farm operations. Approximately $91.89 \%$ of farmers checked the expiration date before buying antibiotics and $13.51 \%$ had special intension to some brands before buying antibiotics. Approximately $85.14 \%$ of farmers used antibiotic doses and $87.84 \%$ farmers followed the antibiotic dosing period recommended by the prescribing physician. Most of the farmers (90.54\%) thrown expired and leftover antibiotics in the open environments. The farm litter or manure had diversified used and management with $39.19 \%$ kept in open pit; $33.78 \%$ used in fish farm; $13.51 \%$ used for biogas plant and $5.41 \%$ used for agricultural land. It was observed that the dead birds were disposed by different means, buried in the ground (58.10\%), thrown in the field (9.45\%), thrown in the bush near the farm (6.75\%), thrown in the garbage $(9.45 \%)$ and thrown in the water (13.51\%). A number of $91.89 \%$ respondent's sprayed disinfectant with regular interval to clean the farm premises. Almost none of the farmers had no footbath $(95.95 \%)$ and $63.51 \%$ had no vaccination schedule so far. The practices of poultry farmers has shown in Table 4. 
Practices of the poultry farmers

\begin{tabular}{|c|c|c|}
\hline Practices & Number (n) & Percentage (\%) \\
\hline \multicolumn{3}{|c|}{ 1. Do you follow any prescription that was generated for previous batch of your own or of any other farm? } \\
\hline Yes & 10 & 13.51 \\
\hline No & 61 & 82.43 \\
\hline Do not know & 3 & 4.05 \\
\hline \multicolumn{3}{|c|}{ 2. Do you take physician prescription or advices when you buy antibiotics? } \\
\hline Yes & 47 & 63.51 \\
\hline No & 27 & 36.49 \\
\hline \multicolumn{3}{|c|}{ 3. Did the prescriber/adviser do antimicrobial susceptibility testing (AST) before selecting antibiotics? } \\
\hline Yes & 0 & 0 \\
\hline No & 74 & 100 \\
\hline \multicolumn{3}{|c|}{ 4. Do you check the expiry date of antibiotics before using it for your chicken? } \\
\hline Yes & 68 & 91.89 \\
\hline No & 6 & 8.11 \\
\hline \multicolumn{3}{|c|}{ 5. From whom usually you get suggestions or treatment for your sick chicken? } \\
\hline Govt. veterinary physician & 9 & 12.16 \\
\hline Private veterinary physician & 45 & 60.81 \\
\hline Feed/chick/medicine company representative & 6 & 8.11 \\
\hline Feed/chick/medicine seller & 2 & 2.70 \\
\hline Veterinary paraprofessional & 3 & 4.05 \\
\hline Self-medication & 5 & 6.76 \\
\hline Family/friends & 1 & 1.35 \\
\hline Other animal raisers & 3 & 4.05 \\
\hline \multicolumn{3}{|l|}{ 6. Why did you use antibiotics to your chicken? } \\
\hline For treatment of diseases & 65 & 87.84 \\
\hline For prevention of infection & 4 & 5.41 \\
\hline For increasing egg production (in chicken) & 1 & 1.35 \\
\hline For growth promotion & 1 & 1.35 \\
\hline Others..................... & 3 & 4.05 \\
\hline \multicolumn{3}{|c|}{ 7. How have you been given antibiotics in the last 6 months, whether prescription or advices? } \\
\hline Prescription & 44 & 59.46 \\
\hline Advice & 26 & 35.14 \\
\hline
\end{tabular}




\begin{tabular}{|c|c|c|}
\hline Practices & Number (n) & Percentage (\%) \\
\hline Others ......... & 4 & 5.41 \\
\hline \multicolumn{3}{|l|}{ 8. From where did you buy/collect antibiotics? } \\
\hline From animal drug store & 70 & 94.59 \\
\hline From sales person of animal health company & 3 & 4.05 \\
\hline Others ..... & 1 & 1.35 \\
\hline \multicolumn{3}{|l|}{ 9. How the antibiotics were used? } \\
\hline In accordance with the manufacturer instruction & 65 & 87.84 \\
\hline In accordance with previous experiences & 9 & 12.16 \\
\hline \multicolumn{3}{|l|}{ 10. What factors do you prioritize when you buy antibiotics? } \\
\hline expired date & 45 & 60.81 \\
\hline based on recommendations of the drug/feed/chick seller & 4 & 5.41 \\
\hline certain brand/trademark & 10 & 13.51 \\
\hline trusted drug stores & 15 & 20.27 \\
\hline \multicolumn{3}{|l|}{ 11. If the antibiotic was expired, what would you do? } \\
\hline Stop using & 71 & 95.95 \\
\hline No answer/don't know & 2 & 2.70 \\
\hline Other & 1 & 1.35 \\
\hline \multicolumn{3}{|l|}{ 12. Did you use suggested/recommended dose of antibiotics? } \\
\hline Yes & 63 & 85.14 \\
\hline No, I used higher dose & 6 & 8.11 \\
\hline No, I used lower dose & 2 & 2.70 \\
\hline Do not know & 3 & 4.05 \\
\hline \multicolumn{3}{|c|}{ 13. Did you administer antibiotic for suggested duration to your chicken? } \\
\hline Yes & 65 & 87.84 \\
\hline No, I used for longer duration & 3 & 4.05 \\
\hline No, I used for shorter duration & 3 & 4.05 \\
\hline Do not know & 3 & 4.05 \\
\hline \multicolumn{3}{|c|}{ 14. Where do you dispose or use the litter or manure of your farm? } \\
\hline Biogas plant & 10 & 13.51 \\
\hline Close pit & 2 & 2.70 \\
\hline Fish farm & 25 & 33.78 \\
\hline Open pit & 29 & 39.19 \\
\hline
\end{tabular}




\begin{tabular}{|c|c|c|}
\hline Practices & Number (n) & Percentage (\%) \\
\hline Agricultural land & 4 & 5.41 \\
\hline Others & 4 & 5.41 \\
\hline \multicolumn{3}{|c|}{ 15. How do you dispose the dead birds? } \\
\hline Bury in the ground & 43 & 58.10 \\
\hline Throw in the field & 07 & 9.45 \\
\hline Throw in the bush near the farm & 05 & 6.75 \\
\hline Throw in the garbage & 07 & 9.45 \\
\hline Throw in the water & 10 & 13.51 \\
\hline \multicolumn{3}{|c|}{ 16. Do you use disinfectant with regular interval to clean your farm premises? } \\
\hline Yes & 68 & 91.89 \\
\hline No & 06 & 8.10 \\
\hline \multicolumn{3}{|c|}{ 17. Do you have foot bath in your farm? } \\
\hline Yes & 3 & 4.05 \\
\hline No & 71 & 95.95 \\
\hline \multicolumn{3}{|c|}{ 18. Do you follow any vaccination schedule? } \\
\hline Yes & 27 & 36.48 \\
\hline No & 47 & 63.51 \\
\hline \multicolumn{3}{|c|}{ 19. Where did you dispose left over or expire antibiotics? } \\
\hline Throw in the open environment & 67 & 90.54 \\
\hline Bury in the ground & 5 & 6.75 \\
\hline Throw in the water & 2 & 2.7 \\
\hline
\end{tabular}

\subsection{Association between knowledge and practice}

The level of knowledge was not satisfactory, and practices were poor for all farmers. A significant higher association was found between the level of education and knowledge; level of education with farm practices such as choice of antibiotics, determining doses and duration of antibiotics, dispose of farm wastages, dispose of dead birds, farm biosecurity and vaccination coverage $(p<0.05)$. Similarly, significant association was also found between experiences and farm practices such as choice of antibiotics, determining doses and duration of antibiotics, dispose of farm wastages, dispose of dead birds, farm biosecurity and vaccination coverage $(p<0.05)$. Furthermore, higher statistical association was observed between age and farm practices such as biosecurity, vaccination coverage, dispose of dead birds and dispose of farm wastages $(p<0.05)$.

\section{Discussion}

Poultry farming, particularly broiler and layer, is considered the hotspot in using antimicrobials for therapeutic and nontherapeutic purposes. Conversely, it is thought to be that antimicrobial misuse, abuse and overuse are common practices in poultry rearing communities. Poultry growers believed that without antimicrobials, poultry farms would not be viable 
and the prevalence of the disease would be higher. Most poultry farmers are illiterate and are not familiar with modern poultry farming practices such as vaccination, biosecurity, waste management and the proper uses of antimicrobials. In our study, we evaluated the knowledge, attitude, and practices (KAP) of poultry farmers regarding AMU, AMR and farm hygiene management. The study described demographic information of farmers, including livelihoods, farm size, and income, retroactive linkages with feed and chick vendors. The study revealed information on farm waste management, in particular the disposal of dead birds, farm litter and fecal waste throwing into environment, aquaculture and agricultural system. The findings of the study would suggest to improve the practice of the famers about the adoption of good farming practices as well as policy interventions for commercial poultry operations. However, the modalities of our study was more likely to be aligned with other previous studies on antibiotic use and resistance (Chapot et al., 2021; Hassan et al., 2021; Ozturk et al., 2019).

Mostly poultry producers in our study were aged below 30 years old with male were predominate and highest percentage of farmers were secondary certificate holder. Most of the farmers reported as poultry farming was their main occupation rather than agriculture and fisheries. Most poultry farmers had on an average 4-6 years of experience in poultry farming. While maximum farmers were familiar with antibiotics, but no one heard about antibiotic resistance. Overall, demographic picture of the poultry farmers was similar with some other former studies. A study conducted in Vietnam reveled poultry producers were mostly aged between 30 and 60 years old and they had secondary school education (Pham-Duc et al., 2019). A study conducted in Bangladesh showed all the respondents were male, and had age between 18 to 30 years with farming experiences 8-12 years and education level was higher secondary and poultry farming regarded as the primary family income source (Hassan et al., 2021).

Our study shown that antimicrobial use was very common in the commercial poultry farms, as almost all layer producers administered antimicrobials to their flocks. Significant antimicrobial use despite no clinical signs, non-adherence to withdrawal periods, sales of antimicrobials without prescription of licensed veterinary practitioners and self-medication have often been reported. Even none of the farmers maintained any formal records on the history of antimicrobial use. Lack of reliable and accurate data on the extent of antibiotic use in Southeast Asian livestock production (Coyne et al., 2019; Goutard et al., 2017; Kakkar et al., 2018) and in particular, from commercial layer poultry settings in Bangladesh (Ferdous et al., 2019; Saiful Islam et al., 2016) has been identified earlier. One study demonstrated that farmers regularly use antibiotics, including those that are not allowed to be used in poultry. Multiple antibiotics have been administered since the first day of the production cycle to the point of sale. It was found in a study that farmers were used antibiotics ubiquitously for growth promotion and prophylaxis as a risk-management measure (Begum et al., 2013). A study shown that most commercial poultry producers procured antibiotics directly from feed dealers or even directly from pharmaceutical company (GARP, 2018). Other studies shown that most farmers ( $>60 \%)$ used antibiotics without the prescription of the veterinarians (Saiful Islam et al., 2016). Dealers create functional links between input producers and smallholder farmers by sourcing from large companies through their networks and self-credit. Dealers purchase production inputs with credit from the manufacturers and supply it to farms with credits and purchase harvested products from the small farmers, thus keeping the production cycle moving (Mandal et al., 2017). Pharmaceutical representatives are always focused on achieving the sales target and maintaining ongoing liaison with dealerships. Sometimes, to promote the sale of antibiotics pharmaceutical companies provide their own veterinary assistance through dealers to small farmers. There is a substantial penetration and promotion of animal drug usage by pharmaceutical companies and their agents (Roess et al., 2013).

Most farmers have used antimicrobials for therapeutic and prophylaxis purposes. Prophylactic use of antimicrobials can occur due to a lack of knowledge and frequent advice from the drug vendor. The farmers believed that preventive usage of antimicrobials might reduce the disease burden and to stop frequently occurring poultry diseases (Roess et al., 2013) or because vaccination against poultry diseases has not been carried out. In addition, farmers believed that prophylactic use of antibiotics could save veterinary costs and treatment costs by reducing the prevalence of illness. (Okeke et al., 
2005). Farmers were not interested in going to a local veterinary hospital because of communication problems and sometimes lack of self-confidence and reluctant attitude. Laboratory confirmation of poultry diseases and antimicrobial susceptibility testing facilities were not available in rural Bangladesh. Thus, farmers might be unable to use the facility of laboratories to diagnose diseases, which could result in a widespread prophylactic administration of antimicrobials based on farmers' perceptions of disease risk or their own experience. Farmers did not report the use of antimicrobials as growth promoters. It must inform the farmers about the unnecessary uses of antimicrobials for growth promotion and preemptive purposes and might abstain from using antimicrobials for this purpose (Saiful Islam et al., 2016). Preventive use of antibiotics in commercial poultry production is also common in other Asian countries, including Cambodia, Indonesia, Vietnam and Thailand (Coyne et al., 2019).

There few antimicrobials were common and frequently administered in the poultry farming in our study area such as were penicillin, ampicillin, cloxacillin, gentamicin, streptomycin, oxytetracycline, ceftriaxone, ciprofloxacin, amoxicillin, sulfamethoxazole-trimethoprim and tylosin. Among these, ciprofloxacin and tylosin are considered 'Highest Priority Critically Important Antimicrobials' for public health (WHO, 2019). Indeed, ciprofloxacin and tylosin are used as the last resort for the treatment of infectious diseases. Among these, tylosin is used for the treatment of MDR Salmonella spp., and Shigella infections, Campylobacter spp. and Legionella whilst ciprofloxacin is used for the treatment of MDR Salmonella spp., and Campylobacter spp. (WHO, 2020). It was recommended that ciprofloxacin and tylosin should not to be used as first choice of therapy in poultry and only can be administered after culture and sensitivity testing of the pathogens. In fact, ciprofloxacin and colistin should never be administered to feed-producing animals, including chickens, in the absence of clinical signs (OIE, 2020). Surprisingly, many farmers have used antimicrobials (including ciprofloxacin, tylosin and colistin) without noticing clinical signs.

It has been observed that poultry farmers of the study areas administered antimicrobials through drinking water which is similar with preceding findings (Masud et al., 2020). Bangladesh has enacted the "animal and fish feed act 2010" that prohibits the mixing of antimicrobials with animal feed and provides for a penalty if anybody violate the act (MoFL, 2010). However, some farmers may have broken the law regarding antimicrobials in feed, even though they did not admit it. Farmers had no clear conception about antimicrobial residue and withdrawal period and were selling eggs while administering antimicrobials (Ferdous et al., 2019). A lack of monitoring from governmental agencies had been previously identified as a reason why withdrawal periods were not followed by farmers (Imam et al., 2020). It is suggested to have surveillance of farm management practices, as well as surveillance of antimicrobial residues in accordance with Codex standards (FAO, 2020).

Vaccines are promising alternatives to antibiotics (WHO, 2014). Numerous studies have shown that the use of various bacterial and viral vaccines in animal populations can lead to significant reductions in antibiotic consumption (Murphy et al., 2017). Vaccines can be used to prevent or control infections in animal populations, or to minimize clinical symptoms and minimize post-infection (Holt and Gast, 2004). Conceptually, vaccines reduce the risk of developing antimicrobial resistance by preventing infection and reducing the need for antibiotics to treat primary or secondary bacterial infections after viral or parasitic infections. In addition, vaccines help to eliminate specific pathogens as the cause of the disease and allow the use of narrower spectrum antibiotics by reducing the pressure of the disease in the population by boosting herd immunity (Lipsitch and Siber, 2016). Vaccine has potential effects on the reduction of bacterial population density and consequent resistance gene (Lipsitch and Siber, 2016). Biosafety is a powerful tool for reducing antibiotic consumption in animals. Improving biosecurity practices means that bacteria have less chance of developing resistance and that antibiotics remain effective when they are needed to treat the disease.

Our research revealed that poultry farm hygiene was not up to the mark and farm waste was not well managed or decomposed. Direct poultry farm waste is drained to the nearest pond for aquaculture and, to a certain extent, to agricultural land. In addition, farmers thrown the dead or diseased bird directly into nearby land or water sources. 
Consequently, poultry farm waste has polluted the environment and may exaggerate the occurrence of AMR pathogens in the environment. Poultry production generates significant amounts of excretion including solid waste and wastewater. These findings have similar alignment with several previous reports (Gupta et al., 1997; Kelley et al., 1998; Riedle et al., 2006; Stephenson et al., 1990). Manure is the most abundant garbage. It is commonly found that antibiotic-fed poultry can secrete AMR bacteria and subsequently shed into the soil environment (Bengtsson-Palme et al., 2018; Hudson et al., 2017). The majority of antimicrobials used in veterinary practices retain activity after renal or biliary excretion and plays crucial role to develop environmental resistance (Thanner et al., 2016). Fecal contamination is considered to be important drivers to the spread of pathogenic and AMR bacteria across the poultry production cycle (Imam et al., 2020). Fecal contamination can also contribute to spread of resistant determinants into soil, surface water, ground water, and agricultural crops (Su et al., 2015). Poultry production operations utilize untreated water that could subsequently expose poultry to resistant bacteria (Talukdar et al., 2013).

Changing regulatory frameworks is extremely difficult. Currently, there is no antimicrobial stewardship program in alignment with national strategy in place to control antimicrobials in food animals in Bangladesh. The Ministry of Health and Family Welfare has developed a National Action Plan (2017-2022) to contain AMR in Bangladesh (DGHS, 2017), but unfortunately limited action have been taken (Orubu et al., 2020). Also, practicing over-the-counter sales of antimicrobials without the prescription from a registered veterinarian. A recent ruling by the High Court Division of the Supreme Court of Bangladesh directed antimicrobial sales should only be made with the prescription of registered physician (Daily Star, 2019). Based on the results of this study, it is recommended that farmers should keep records of antimicrobials usage with dosage and duration of administration against which diseases or clinical signs. Education or extension programs for poultry farmers on the prudent use of antimicrobials as well farm hygiene management are highly appreciated. Furthermore, farmer should be educated on withdrawal periods for antimicrobials along with the benefits of vaccination and biosecurity in poultry farm operations. The good biosecurity, infection control practices, disease prevention and waste management must be practiced in order to reduce antimicrobial use. The main players in the poultry industry, which are involved with the use of antimicrobials, are farmers, feed and chick traders, private veterinarians, traditional healers and para-professionals. Moreover, in practice, easy access to "over the counter" antimicrobials are available at veterinary medicine stores without prescription.

The level of knowledge was not satisfactory, and practices were poor for all farmers. A significant higher association was found between the level of education and knowledge; level of education with few farm practices such as choice of antibiotics, determining doses and duration of antibiotics, disposal of farm wastages, disposal of dead birds, farm biosecurity and vaccination coverage $(\mathrm{p}<0.05)$. Similar significant association was observed by different researchers at home and abroad (Adesokan and Raji, 2014; Ansari-Lari et al., 2010; Siddiky et al., 2022; Tegegne and Phyo, 2017). Previously the significant association was disclosed between the level of education and practice by researchers (Hassan et al., 2021; Siddiky et al., 2022). It was found that the respondents' many years of experience in poultry farming were associated with good farm hygienic practices (Hassan et al., 2021).

This study contained a number of limitations. Firstly, geographical representation with a small number of farmers was taken into consideration. The study was conducted in a small cluster of commercial poultry farming community which may have some different practices due to geographic location, culture and access to inputs and farming practices compared with other parts of the country. Second, the quality of some of the interview data could have been influenced by recall and self-reported practices in participants. Although this study evaluated the knowledge, attitude, and practices associated with AMU, AMR and farm hygiene measures, but more robust countrywide survey is needed to understand the cultural, social, and agro-ecological factors to identify the differences of KAP in different region of the country.

\section{Conclusion}


Antimicrobials are commonly used for therapeutic, preventive and growth promotion in the poultry farms. Farmers had inadequate knowledge and poor practices regarding use of antimicrobials and farm hygiene precautions in the production cycle. Farmer's education, experiences and age played significant role towards the rational use of antibiotics and good farm management interventions. In addition, a rigorous regulatory holistic approach on antibiotic use, marketing and prescribing helps to improve antibiotic misuse and reduce antibiotic resistance. It is suggested to improve farmers' knowledge, attitude and practices through good governance, motivation, training and outreach. Farmers should be made aware of good farm hygienic practices, on-farm biosecurity and the vaccination campaign. All farms must be registered with the livestock departments for continuous monitoring and surveillance of farm biosecurity, waste management and antimicrobial uses regime.

\section{Declarations}

\section{Declaration of competing interest}

The authors declare no actual or potential conflict of interest with other people or organizations that might influence the associated research.

\section{Acknowledgments}

This work was supported by the project on "combating the threats of antimicrobial resistance and zoonotic diseases to achieve the GHSA in Bangladesh" (Grant Number: 5 NU2GGH002077). The authors would like to thank the poultry farmers for their full support during the survey.

\section{References}

1. Abah, H.O., Nwankwo, A.U., Orgem, C.M., 2019. Waste Management Practices in Selected Poultry Farms and its Effect on the Environment and Human Health in Makurdi, Nigeria. Int. J. Environ. Agric. Biotech. 4(1), 121-127. https://doi.org/10.22161/ijeab/4.1.20

2. Adeoye, P.A., Hasfalina, C.M., Amin, M.S.M., Thamer, A. M., Akinbile, C.O., 2014. Environmental Implication of Poultry Waste Generation and Management Techniques in Minna, Semi-arid Region of Nigeria. Annu. Res. Rev. Biol. 4(10), 1669-1681. https://doi.org/10.9734/ARRB/2014/8525

3. Adesokan, H.K., Raji, A.O.Q., 2014. Safe meat-handling knowledge, attitudes and practices of private and government meat processing plants' workers: implications for future policy. J. Prev. Med. Hyg. 55(1), 10-16.

4. Ansarey, F.H., 2012. Prospects of poultry industry in Bangladesh. Proceedings of the Seminar and Reception on Animal Husbandry Education and Profession in Bangladesh- A Journey of 50 Years, (AHEPB'12), Dhaka, Bangladesh. pp. 62-65.

5. Ansari-Lari, M., Soodbakhsh, S., Lakzadeh, L., 2010. Knowledge, attitudes and practices of workers on food hygienic practices in meat processing plants in Fars, Iran. Food Control 21, 260-263.

https://doi.org/10.1016/j.foodcont.2009.06.003

6. BBS, 2017. Yearbook of Agricultural Statistics of Bangladesh 2016. Dhaka: Bangladesh Bureau of Statistics.

7. Begum, I.A., Alam, M.J., Rahman, S., Van Huylenbroeck, G., 2013. An assessment of the contract farming system in improving market access for smallholder poultry farmers in Bangladesh. In: Contract Farming for Inclusive Market Access. Food and Agriculture Organization of the United Nations, Rome, Italy. pp. 39-56.

8. Bengtsson-Palme, J., Kristiansson, E., Larsson, D.G.J., 2018. Environmental factors influencing the development and spread of antibiotic resistance. FEMS Microbiol. Rev. 42. https://doi.org/10.1093/femsre/fux053 
9. Broom, A., Broom, J., Kirby, E., 2014. Cultures of resistance? A Bourdieusian analysis of doctors' antibiotic prescribing. Soc. Sci. Med. 110, 81-88. https://doi.org/10.1016/j.socscimed.2014.03.030

10. Chan, K.Y.A., B, L.V.Z., Meszaros, I.A., Downie, A.C., Joseph, S.D., 2008. Using poultry litter biochars as soil amendments. Aust. J. Soil Res. 46, 437-444.

11. Chapot, L., Sarker, M.S., Begum, R., Hossain, D., Akter, R., Hasan, M.M., Bupasha, Z.B., Bayzid, M., Salauddin, M., Parvej, M.S., Uddin, A.H.M.M., Hoque, F., Chowdhury, J., Ullah, M.N., Rahman, M.K., Siddiky, N.A., Fournié, G., Samad, M.A., 2021. Knowledge, Attitudes and Practices Regarding Antibiotic Use and Resistance among Veterinary Students in Bangladesh. Antibiotics 10. https://doi.org/10.3390/antibiotics10030332

12. Coyne, L., Arief, R., Benigno, C., Giang, V.N., Huong, L.Q., Jeamsripong, S., Kalpravidh, W., McGrane, J., Padungtod, P., Patrick, I., Schoonman, L., Setyawan, E., Harja Sukarno, A., Srisamran, J., Ngoc, P.T., Rushton, J., 2019. Characterizing Antimicrobial Use in the Livestock Sector in Three South East Asian Countries (Indonesia, Thailand, and Vietnam). Antibiot. (Basel, Switzerland) 8, 33. https://doi.org/10.3390/antibiotics8010033

13. Da Silva, C.A., Rankin, M., 2014. Contract Farming for Inclusive Market Access. Food and Agriculture Organization of the United Nations, Rome, Italy. pp. 227.

14. Daily Star, 2019. Local Correspondent. Prescription Now Must for Antibiotics. https://www.thedailystar.net/frontpage/news/prescription-now-must-antibiotics-1734958

15. DGDA, 2016. National Drug Policy 2016. Directorate General of Drug Administration, Ministry of Health and Family Welfare, Government of the People's Republic of Bangladesh. https://www.dgda.gov.bd/index.php/laws-andpolicies/261-national-drug-policy-2016-english-version/file

16. DGDA, 2018. Antibiotic Use and Resistance in Bangladesh: Situation Analysis and Recommendations. GARPBangladesh Secretariat, Dhaka.

17. DGHS, 2017. National Action Plan. Antimicrobial Resistance Containment in Bangladesh 2017-2022. Directorate General of Health Services, Disease Control Division, Communicable Disease Control Program, Ministry of Health and Family Welfare, Government of the People's Republic of Bangladesh. https://www.flemingfund.org/wpcontent/uploads/d3379eafad36f597500cb07c21771ae3.pdf

18. FAO, 1963. Codex Alimentarius. http://www.fao.org/faowho-codexalimentarius/en/

19. Ferdous, J., Sachi, S., Noman, Z. Al, Hussani, S.M.A.K., Sarker, Y.A., Sikder, M.H., 2019. Assessing farmers' perspective on antibiotic usage and management practices in small-scale layer farms of Mymensingh district, Bangladesh. Vet. world 12, 1441-1447. https://doi.org/10.14202/vetworld.2019.1441-1447

20. GARP, 2018. Situation analysis and recommendations on antibiotic resistance in Bangladesh 1-122.

21. Goutard, F.L., Bordier, M., Calba, C., Erlacher-Vindel, E., Góchez, D., de Balogh, K., Benigno, C., Kalpravidh, W., Roger, F., Vong, S., 2017. Antimicrobial policy interventions in food animal production in South East Asia. BMJ 358, j3544. https://doi.org/10.1136/bmj.j3544

22. Gupta, G., Borowiec, J., Okoh, J., 1997. Toxicity Identification of Poultry Litter Aqueous Leachate. Poult. Sci. 76, 1364-1367. https://doi.org/10.1093/ps/76.10.1364

23. Hamid, M.A., Rahman, M.A., Ahmed, S., Hossain, K.M., 2017. Status of poultry industry in Bangladesh and the role of private sector for its development. Asian J. Poult. Sci. 11, 1-13. https://dx.doi.org/10.3923/ajpsaj.2017.1.13

24. Hassan, M.M., 2020. Scenario of Antibiotic Resistance in Developing Countries, Antimicrobial Resistance-A One Health Perspective, Mihai Mareș, Swee Hua Erin Lim, Kok-Song Lai and Romeo-Teodor Cristina, IntechOpen. https://doi.org.10.5772/intechopen.94957

25. Hassan, M.M., Kalam, M.A., Alim, M.A., Shano, S., Nayem, M.R.K., Badsha, M.R., Al Mamun, M.A., Hoque, A., Tanzin, A.Z., Nath, C., Khanom, H., Khan, S.A., Islam, M.M., Uddin, M.B., Islam, A., 2021. Knowledge, Attitude, and Practices on 
Antimicrobial Use and Antimicrobial Resistance among Commercial Poultry Farmers in Bangladesh. Antibiotics 10. https://doi.org/10.3390/antibiotics10070784

26. Holt, P.S., Gast, R.K., 2004. Effects of prior coinfection with different Salmonella serovars on the progression of a Salmonella enterica serovar enteritidis infection in hens undergoing induced molt. Avian Dis. 48, 160-166. https://doi.org/10.1637/7101

27. Hudson, J.A., Jones, G., Whittingham, M.J., Hudson, J.A., Frewer, L.J., Jones, G., Brereton, P.A., Whittingham, M.J., Stewart, G., 2017. The agri-food chain and antimicrobial resistance: A review. Trends Food Sci. Technol. 69, $131-147$.

28. Imam, T., Gibson, J.S., Foysal, M., Das, S.B., Gupta, S. Das, Fournié, G., Hoque, M.A., Henning, J., 2020. A CrossSectional Study of Antimicrobial Usage on Commercial Broiler and Layer Chicken Farms in Bangladesh. Front. Vet. Sci. 7, 1044. https://doi.org/10.3389/fvets.2020.576113

29. Kakkar, M., Chatterjee, P., Chauhan, A.S., Grace, D., Lindahl, J., Beeche, A., Jing, F., Chotinan, S., 2018. Antimicrobial resistance in South East Asia: time to ask the right questions. Glob. Health Action. 11, 1483637. https://doi.org/10.1080/16549716.2018.1483637

30. Kelley, T.R., Pancorbo, O.C., Merka, W.C., Barnhart, H.M., 1998. Antibiotic resistance of bacterial litter isolates. Poult. Sci. 77, 243-247. https://doi.org/10.1093/ps/77.2.243

31. Khatun, R., Howlader, M.A.J., Ahmed, S., Islam, M.N., Hasan, M.A., Haider, M.S., Mahmud, M.S., 2016. Impact of training and monitoring of drug used by small scale poultry farmers at different location of Bangladesh. AJFSH. 2(6), 134-140.

32. Laxminarayan, R., Duse, A., Wattal, C., Zaidi, A.K.M., Wertheim, H.F.L., Sumpradit, N., Vlieghe, E., Hara, G.L., Gould, I.M., Goossens, H., Greko, C., So, A.D., Bigdeli, M., Tomson, G., Woodhouse, W., Ombaka, E., Peralta, A.Q., Qamar, F.N., Mir, F., Kariuki, S., Bhutta, Z.A., Coates, A., Bergstrom, R., Wright, G.D., Brown, E.D., Cars, O., 2013. Antibiotic resistance-the need for global solutions. Lancet. Infect. Dis. 13, 1057-1098. https://doi.org/10.1016/S1473-3099(13)70318-9

33. Lipsitch, M., Siber, G.R., 2016. How Can Vaccines Contribute to Solving the Antimicrobial Resistance Problem? MBio. 7(3), e00428-16. https://doi.org/10.1128/mBio.00428-16

34. Saiful Islam, K.B.M., Shiraj-Um-Mahmuda, S., Hazzaz-Bin-Kabir, M., M Saiful, K.B., 2016. Antibiotic Usage Patterns in Selected Broiler Farms of Bangladesh and their Public Health Implications. J. Public Heal. Dev. Ctries. 2(3), 276-284.

35. Mandal, M.S., Khan, A.L.F.R., 2017. Poultry industry in Bangladesh: Which way to sustainable development. In: Proceedings of the 10th International Poultry Show and Seminar. World's Poultry Science Association Bangladesh Branch.

36. Masud, A. Al, Rousham, E.K., Islam, M.A., Alam, M.U., Rahman, M., Mamun, A. Al, Sarker, S., Asaduzzaman, M., Unicomb, L., 2020. Drivers of Antibiotic Use in Poultry Production in Bangladesh: Dependencies and Dynamics of a Patron-Client Relationship. Front. Vet. Sci. 7, 78. https://dx.doi.org/10.3389\%2Ffvets.2020.00078

37. MoFL, 2010. Fish Feed and Animal Feed Act 2010. Bangladesh Gazette. http://extwprlegs1.fao.org/docs/pdf/bgd165024.pdf

38. MoHFW, 2017. National Action Plan: Antimicrobial Resistance Containment in Bangladesh 2017-2022; Ministry of Health and Family Welfare, Directorate General of Health Services: Dhaka, Bangladesh. pp. 1-12.

39. Moreki, J.C., Keaikitse, T., 2013. Poultry waste management practices in selected poultry operations around Gaborone, Botswana. Int. J. Curr. Microbiol. App. Sci. 2(7), 240-248.

40. Murphy, D., Ricci, A., Auce, Z., Beechinor, J.G., Bergendahl, H., Breathnach, R., Bureš, J., Da Silva, D., Pedro, J., Hederová, J., 2017. EMA and EFSA Joint Scientific Opinion on measures to reduce the need to use antimicrobial agents in animal husbandry in the European Union, and the resulting impacts on food safety (RONAFA). EFSA J, 15:4666. 
41. OIE, 2020. OIE Annual Report on Antimicrobial Agents Intended for Use in Animals: Better Understanding of the Global Situation.

https://www.oie.int/fileadmin/Home/eng/Our_scientific_expertise/docs/pdf/AMR/A_Fourth_Annual_Report_AMR.pdf

42. Okeke, I.N., Laxminarayan, R., Bhutta, Z.A., Duse, A.G., Jenkins, P., O’Brien, T.F., Pablos-Mendez, A., Klugman, K.P., 2005. Antimicrobial resistance in developing countries. Part I: recent trends and current status. Lancet. Infect. Dis. 5 , 481-493. https://doi.org/10.1016/S1473-3099(05)70189-4

43. Onu, D.O., Offor, E.I., Okpara, B.O., 2015. Poultry wastes management strategies and environmental implications in Abia State. IRJAS. 5(6), 159-164.

44. Orubu, E.S.F., Zaman, M.H., Rahman, M.T., Wirtz, V.J., 2020. Veterinary antimicrobial resistance containment in Bangladesh: Evaluating the national action plan and scoping the evidence on implementation. J. Glob. Antimicrob. Resist. 21, 105-115. https://doi.org/10.1016/j.jgar.2019.09.020

45. Ozturk, Y., Celik, S., Sahin, E., Acik, M.N., Cetinkaya, B., 2019. Assessment of Farmers' Knowledge, Attitudes and Practices on Antibiotics and Antimicrobial Resistance. Animals (Basel). 49(9), 653. https://doi.org/10.3390/ani9090653

46. Pham-Duc, P., Cook, M.A., Cong-Hong, H., Nguyen-Thuy, H., Padungtod, P., Nguyen-Thi, H., Dang-Xuan, S., 2019. Knowledge, attitudes and practices of livestock and aquaculture producers regarding antimicrobial use and resistance in Vietnam. PLoS One. 14, e0223115. https://doi.org/10.1371/journal.pone.0223115

47. Roess, A.A., Winch, P.J., Ali, N.A., Akhter, A., Afroz, D., El Arifeen, S., Darmstadt, G.L., Baqui, A.H., Group, B.P.S., 2013. Animal husbandry practices in rural Bangladesh: potential risk factors for antimicrobial drug resistance and emerging diseases. Am. J. Trop. Med. Hyg. 89, 965-970. https://doi.org/10.4269/ajtmh.12-0713

48. Saleque, M.A., Silvi, A.N., 2020. Poultry Industry and Bird Flu in Bangladesh - Current State, Challenges and Solutions. ACl Agribusiness, 245, Tejgaon Industrial Area, Dhaka-1208, Bangladesh.

49. Siddiky, N.A., Khan, M.S.R., Sarker, M.S., Bhuiyan, M.K.J., Mahmud, A., Rahman, M.T., Ahmed, M.M., Samad, M.A., 2022. Knowledge, attitude and practice of chicken vendors on food safety and foodborne pathogens at wet markets in Dhaka, Bangladesh. Food Control. 131, 108456. https://doi.org/10.1016/j.foodcont.2021.108456

50. Singh, P., Mondal, T., Sharma, R., Mahalakshmi, N., Gupta, M., 2018. Poultry Waste Management. Int. J. Curr. Microbiol. App. Sci. 7(8), 701-712. https://doi.org/10.20546/ijcmas.2018.708.077

51. Stephenson, A.H., McCaskey, T.A., Ruffin, B.G., 1990. A survey of broiler litter composition and potential value as a nutrient resource. Biol. Wastes. 34, 1-9. https://doi.org/https://doi.org/10.1016/0269-7483(90)90139-J

52. Su, J.-Q., Wei, B., Ou-Yang, W.-Y., Huang, F.-Y., Zhao, Y., Xu, H.-J., Zhu, Y.-G., 2015. Antibiotic resistome and its association with bacterial communities during sewage sludge composting. Environ. Sci. Technol. 49, 7356-7363. https://doi.org/10.1021/acs.est.5b01012

53. Talukdar, P.K., Rahman, Mizanur, Rahman, Mahdia, Nabi, A., Islam, Z., Hoque, M.M., Endtz, H.P., Islam, M.A., 2013. Antimicrobial resistance, virulence factors and genetic diversity of Escherichia coli isolates from household water supply in Dhaka, Bangladesh. PLoS One. 8, e61090. https://doi.org/10.1371/journal.pone.0061090

54. Tegegne, H.A., Phyo, H.W.W., 2017. Food safety knowledge, attitude and practices of meat handler in abattoir and retail meat shops of Jigjiga Town, Ethiopia. J. Prev. Med. Hyg. 58, E320-E327. https://doi.org/10.15167/24214248/jpmh2017.58.4.737

55. Thanner, S., Drissner, D., Walsh, F., 2016. Antimicrobial Resistance in Agriculture. MBio 7, e02227-15. https://doi.org/10.1128/mBio.02227-15

56. WHO, 2014. Antimicrobial resistance: global report on surveillance. World Health Organization, Geneva.

57. WHO, 2019. Critically Important Antimicrobials for Human Medicine. https://apps.who.int/iris/bitstream/handle/10665/312266/9789241515528-eng.pdf 
58. WHO, 2021. Monitoring Global Progress on Antimicrobial Resistance: Tripartite AMR Country Self-Assessment Survey (TrACSS) 2019-2020: Global Analysis Report, WHO: Geneva, Switzerland.

\section{Figures}

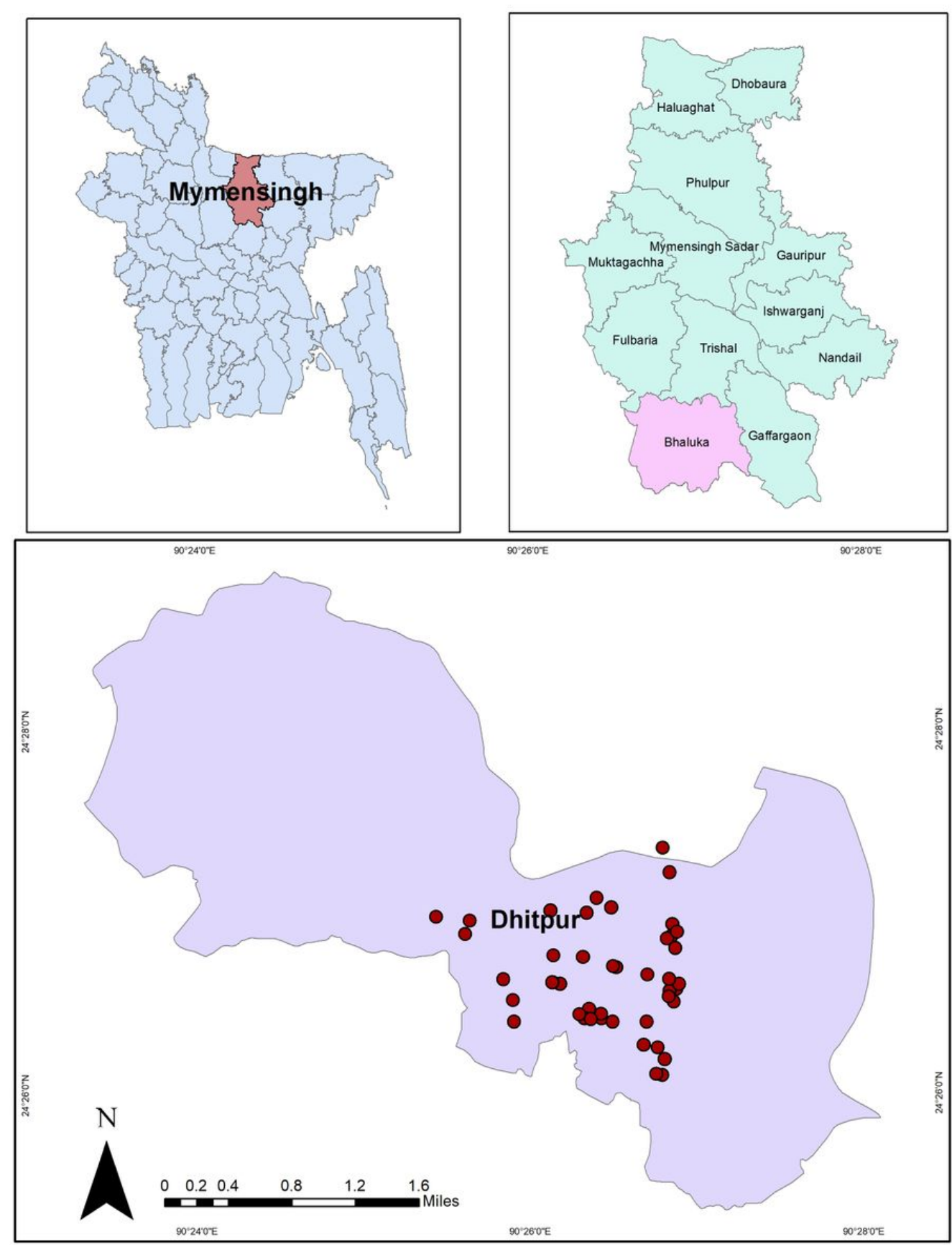

Figure 1

Map indicating the survey areas in Bhaluka sub-districts 